\title{
EU OU MINHA ALMA: \\ ESCOLHAS SUBJETIVAS NO UNIVERSO FICCIONAL DE CLARICE LISPECTOR
}

Gilson Antunes da Silva*

\begin{abstract}
RESUMO: Ponho em evidência o tema das escolhas subjetivas na obra de Clarice Lispector, para demonstrar como algumas de suas personagens efetivam essas opções a partir de dois polos: de um lado, a preferência pela face apolínea da existência; de outro, a eleição da vertente dionisíaca, culminando no gesto afirmativo. Para tanto, elejo como corpus os contos Amor, de Lacos de família, A quinta história, de A legião estrangeira, A fuga, de $A$ bela e a fera e o romance $A$ paixão segundo G.H. Como suporte teórico, valho-me da Psicanálise e da filosofia nietzscheana. Trata-se de um trabalho de natureza bibliográfica pautado na metodologia da Literatura comparada.
\end{abstract}

PALAVRAS-CHAVE: Escolhas subjetivas; Vertentes apolínea e dionisíaca; Gesto afirmativo; Clarice Lispector.

\section{Introdução}

$\mathrm{Na}$ Filosofia, a escolha diz respeito a algum procedimento pelo qual determinada possibilidade é assumida, adotada, decidida ou realizada de um modo específico. Esse conceito está estritamente vinculado ao de possibilidade, de tal forma que não só não há escolha onde não há possibilidade (já que é a própria possibilidade aquilo que se oferece à escolha), como tampouco há possibilidade onde não há escolha. Por outro lado, o conceito de escolha é uma das determinações fundamentais do de liberdade (ABBAGNANO, 2007). Aquele conceito ganhou um lugar especial na filosofia existencialista, sobretudo na obra de Søren Kierkegaard que enfatizou o valor da escolha naquilo que concerne à própria personalidade do homem ou à sua existência.

Na perspectiva de Kierkegaard, a escolha está diretamente relacionada à angústia, conceito caro ao pensamento desse autor. Sua análise do conceito de angústia começa com a leitura do mito da queda de Adão e Eva, quando eles são colocados diante da possibilidade de escolher. Com sua queda, eles passam a existir, no sentido de que a existência humana está condicionada à decisão e à liberdade. A partir dessa existência, instaura-se um outro elemento na vida do ser humano: a angústia (KIERKEGAARD, 1968). Nesse sentido, escolher implica angustiar-se, estranhar-se em si mesmo na busca por uma existência autêntica.

Em Clarice Lispector, a escolha implica o sacrifício, a renúncia, a privação de coisa apreciada. Para ficar com algo, é preciso renunciar outra coisa também importante. É com essa conotação que aparece esse tema no conto "A quinta história", quando a voz que narra

\footnotetext{
* Doutor em Literatura e Cultura pela Universidade Federal da Bahia. Professor do Instituto Federal de Educação, Ciência e Tecnologia Baiano em Valença (Ifbaiano).
} 
se coloca nos seguintes termos: “Áspero instante de escolha entre dois caminhos que, pensava eu, se dizem adeus, e certa de que qualquer escolha seria a do sacrifício: eu ou minha alma. Escolhi” (LISPECTOR, 1999a, p. 76, grifo meu).

O campo das escolhas em Clarice Lispector, além de sacrifício, abarca também a dimensão do pacto que é feito tanto com as forças dionisíacas (o que acontece com Joana, com a narradora de Água viva e com G.H.) como com as forças apolíneas, quando as personagens, após um re(encontro) com as potências vitais, optam por preservar a terceira perna, mantendo-se em seu cotidiano apaziguado (SILVA, 2015).

Na crônica "Dies irae", publicada em 25 de setembro de 1971, o ato de escolher está condicionado à escuta interior, porque "minha escolha depende de eu poder ou não me ouvir”. (LISPECTOR, 1999b, p. 378) Tal gesto, em outra crônica (13 de novembro de 1971), tem caráter indeterminado: "Escolha e ajustamento não tinham hora certa de começar nem acabar, duravam mesmo o tempo de uma vida”. (LISPECTOR, 1999b, p. 386). Entretanto, esse gesto, é sempre o do sacrifício: "Entre o “sim" e o "não” só há um caminho: escolher". (LISPECTOR, 1999c, p. 68).

Objetivo, neste texto, discutir algumas escolhas subjetivas feitas por personagens clariceanas para evidenciar como elas alternam entre dois polos que considero centrais nas narrativas da autora. De um lado, há personagens que optam pela vertente apolínea da existência, quando preferem o equilíbrio do seu cotidiano e decidem viver o apaziguamento de seus dias. De outro, há personagens (penso que essa é a vertente predominante na ficção de Clarice Lispector) que, apesar de todo sofrimento que essa escolha implica, elegem a vertente dionisíaca da existência, fazendo a experiência trágica, na qual a vida é marcada por dilaceramento e repetições. Para evidenciar essas escolhas, elegi três contos representativos da opção pelo mesmo, pela cotidianidade das coisas, pela vida dominada por Eros, pelo mundo equilibrado de Apolo. Trata-se dos contos "Amor", de Laços de família, "A quinta história", de $A$ legião estrangeira e "A fuga", de $A$ bela e a fera. Em contraste a essas mulheres que fazem a opção pela casa, pelo conforto subjetivo, escolhi três personagens que elegeram a vida larga como condição de existência: Joana, de Perto do coração selvagem, a narradora de Água viva e a protagonista de $A$ paixão segundo G.H. Apesar dessas escolhas, nesse segundo bloco, minha análise recairá somente sobre essa última.

Trata-se de um trabalho de natureza comparada que se vale - teoricamente - da Psicanálise e da Filosofia nietzscheana para efetivar a leitura dos textos eleitos como corpus de investigação. Desse modo, este texto é uma construção bibliográfica cujos procedimentos estão centrados na leitura, comparação e análise dos textos aqui selecionados. 


\section{O tripé estável}

Começo esta seção, trazendo, à cena textual, um fragmento do romance $A$ paixão segundo G.H., para refletir acerca da resistência de algumas personagens claricianas em seguir um "destino maior", destoando do gesto afirmativo empreendido por GH e outras heroínas, como fizeram Joana e a protagonista de Água viva (SILVA, 2015). Ao mesmo tempo, utilizo esta mesma imagem para contrapor a coragem de G.H ao medo de outras protagonistas que se negaram a se submeter a uma completa metamorfose, recuando em seu cotidiano doméstico, mantendo assim um "tripé estável" que lhes oferece segurança e estabilidade subjetivas. Vejamos o fragmento!

\footnotetext{
No entanto, na infância as descobertas terão sido como num laboratório onde se acha o que se achar? Foi como adulto então que eu tive medo e criei a terceira perna? Mas como adulto terei a coragem infantil de me perder? perder-se significa ir achando e nem saber o que fazer do que se for achando. As duas pernas que andam, sem mais a terceira que prende. E eu quero ser presa. Não sei o que fazer da aterradora liberdade que pode me destruir. Mas enquanto eu estava presa, estava contente? ou havia, e havia, aquela coisa sonsa e inquieta em minha feliz rotina de prisioneira? ou havia, e havia, aquela coisa latejando, a que eu estava tão habituada que pensava que latejar era ser uma pessoa. É? também, também. (LISPECTOR, 1968, p. 10).
}

Este é um fragmento do primeiro capítulo em que encontramos a protagonista imersa numa dúvida que a consome e a impulsiona, ao mesmo tempo, a compartilhar com o leitor dessa angústia que a mobiliza. Ao realizar este gesto, G.H. faz referência a alguns elementos que merecem nossa atenção: o infantil e a coragem de se perder, a coisa sonsa e inquieta latejando, o adulto criador de uma terceira perna e, por fim, sua feliz rotina de prisioneira. Aqui encontramos dois pares antitéticos muito recorrentes na ficção clariciana: vida represada no cotidiano alienante versus força arrebatadora que desestabiliza e aponta a direção de um destino maior; infantil como lugar da dispersão passional, nascedouro das paixões ainda não domadas, (portanto, vida em potência) versus adulto como lugar do enfraquecimento da vida, recalque da potência do existir, encoberta pelo véu dos investimentos morais e pelos ideais da civilização.

Quanto ao primeiro grupo de oposições, retomo, brevemente, as reflexões desenvolvidas num texto sobre o infantil na obra de Clarice Lispector (SILVA, 2011). Aí, ao analisar o conto "A legião estrangeira" e a vida da pequena Joana, sustento a ideia de que o infantil em Clarice Lispector aparece, principalmente, como o cenário em que as paixões desabrocham em sua potencialidade. Segundo Yudith Rosenbaum (2006), o mundo infantil de 
Clarice Lispector privilegia a infância como o nascedouro das emoções mais ínfimas e estruturantes do psiquismo humano. Nelas, aquilo que o adulto resguarda, esconde, mascara, altera, desvia e simula, a fim de melhor ajustar-se à vida pacificada, à vida social, ganha corpo e expressão, dominando o enredo. Lispector evidencia o mundo infantil repleto de perversões ainda não camufladas pela cultura, expõe o desejo em suas desordens.

Ainda sobre o infantil contraposto ao adulto, a indagação de G.H. ("Mas como adulto terei a coragem infantil de me perder?") evidencia uma outra marca desse universo, remetendo-nos ao pensamento nietzschiano quando o filósofo de Sils Maria associa a criança ao deus Dionísio, naquilo que concerne ao trabalho insistente de montagem e desmontagem, contínua criação e destruição de si mesmo. Ambos representam a força antagônica de edificar e demolir, criar e destruir limites, ordenar e retornar ao caos. É essa "coragem de se perder" que incita G.H. a fazer sua completa metamorfose, tomada por uma compulsão a repetir, a afirmar essa vida que lhe arrasta para "o pior de si”. Aqui há a confluência de duas forças contrárias. Por um lado, há uma potência inconsciente que impele a narradora a retornar, a repetir e a recomeçar; de outro, um desejo consciente do ego em afirmar essa vida que insiste em se repetir, em voltar ao estado de não-eu. Dessa conjunção, produz-se uma disforia, uma disjunção total no seio da personalidade fossilizada do eu que narra. G.H., pela via do retorno, completa a metamorfose ensaiada por Joana e Virgínia. “A travessia da ordem apolínea para a paixão dionisíaca constitui o fim último do drama de Joana e a origem primeira da tragédia de G.H. Joana está sempre perto, mas nunca dentro do coração selvagem da vida. […] G. H. se perde na paixão diluvial da vida em si mesma.” (SOUZA, 1997, p. 134)

Essa coragem de abandonar a "terceira perna" nos remete ao segundo par de oposições representado no fragmento supracitado pelos elementos "a coisa sonsa e inquieta latejando" e "sua feliz rotina de prisioneira". Para discutir tais aspectos, farei uma breve leitura dos contos "Amor", de Laços de família (1997), "A quinta história” de A legião estrangeira (1999a) e "A fuga", de $A$ bela e a fera (1979). Focalizo minha atenção nos aspectos que dizem respeito à resistência das personagens em se entregar a uma vida maior, à "transformação de crisálida em larva úmida" para contrapor à desmedida da protagonista de A paixão em ter a "coragem de um sonâmbulo que simplesmente vai", perdendo-se numa aventura perpassada por dor, solidão e alegria difícil.

Embora arrebatada por essa força de atração contra a qual o eu quase nunca consegue resistir, Ana, protagonista do conto “Amor", após fazer a experiência da "íntima desordem”, prefere retornar ao seu cotidiano e tentar viver como se fosse possível apaziguar a vida com afazeres domésticos, tornando "os dias realizados e belos". O conto se inicia com a narradora 
descrevendo a protagonista no bonde, à procura de uma saída para recalcar alguma coisa sonsa que sempre se insinua na "hora perigosa da tarde". Ana procura conforto, "num suspiro de meia satisfação" no seio da família, acreditando que "a vida podia ser feita pela mão do homem" (LISPECTOR, 1997, p. 30). Ainda assim, apesar de criar "em troca algo enfim compreensível, uma vida de adulto", a dona de casa "sempre tivera necessidade de sentir a raiz firme das coisas", onde a "felicidade insuportável” fosse possível. Há algo que a inquieta e seduz, tornando-a mais vigilante e preocupada: "Sua preocupação reduzia-se a tomar cuidado na hora perigosa da tarde, quando a casa estava vazia sem precisar mais dela" (LISPECTOR, 1997, p. 31). Esse é o momento em que a angústia da castração se insinua, em que Ana é atraída por uma "rede de vazios" tão bem caracterizada na forma como a narradora descreve o ambiente externo, contrastando com o universo subjetivo da protagonista. "Casa vazia" e "móveis limpos" são os significantes usados para fazer esse paralelo entre mundo interior e realidade externa. É desse lugar vazio que Ana foge até se deparar com um nada ainda maior: o cego mascando chicles. Sem saída para resistir, "o mal estava feito" (LISPECTOR, 1997, p. 33). Aqui é da rede de tricô confeccionada por Ana que sai a gema dos ovos partidos na ocasião do tombo provocado pelo movimento brusco do trem. Neste momento, algo retorna e se repete. "O mundo se tornara de novo um mal-estar. Vários anos ruíam, as gemas amarelas escorriam" (LISPECTOR, 1997, p. 33). O recalcado retorna com sua força, desestabilizando, por completo, uma rede subjetiva amalgamada em torno de um eu organizado que agora cede sem recusas. O ovo quebrado é imagem da própria subjetividade cindida, duplicada por forças antagônicas: o de fora (o eu) e o de dentro (o inconsciente, o material recalcado) que se debatem através de suas tentativas de expressão. Como GH, Ana é acometida por um estranhamento nesse instante de crise. "Tudo era estranho, suave demais, grande demais" (LISPECTOR, 1997, p. 35). Algo que deveria ter permanecido secreto e oculto veio à luz, tal como pensara Freud a respeito do unheimlich (FREUD, 2010). Presa ao vazio do cego com o qual se identifica, a personagem vai ao Jardim Botânico onde experimenta a vida em sua potência. Volta para casa, ainda tomada pela experiência vivida com o real da falta, certa de que “a vida é periclitante” (LISPECTOR, 1997, p. 37). Nesse momento, Ana já está consciente de que "a vida é horrível” da qual "não havia como fugir. Os dias que ela forjara haviam-se rompido e a água escapava. Estava diante das ostras" (LISPECTOR,

\footnotetext{
${ }^{1}$ Confirmando essa ideia de que Ana, fixada numa ordem externa tenta esconder uma desordem subjetiva prestes a rebentar, vejamos o que diz Clarice numa crônica de 08/06/1968. "Mas as pessoas que se preocupam demais com a ordem externa é porque internamente estão em desordem e precisam de um contraponto que lhes sirva de segurança” (LISPECTOR, 1999b, p. 109).
} 
1997, p. 38) ${ }^{2}$. Cheia da "pior vontade de viver", Ana questiona-se acerca do que fazer de si depois disso: "O que faria se seguisse o chamado do cego? Iria sozinha..." (LISPECTOR, 1997, p. 38). Mas permanecer nesse estado de choque e de desamparo, embora gozando da crueldade do real, é atemorizador. “Tenho medo, disse” (LISPECTOR, 1997, p. 38). Volta, então, para o seio da família, entretanto, "ao redor havia uma vida silenciosa, lenta e insistente" (LISPECTOR, 1997, p. 39). Reintegra-se nessa atmosfera, mas era ainda "uma mulher bruta que olhava pela janela" (LISPECTOR, 1997, p. 40). A casa é vista, aos olhos de Ana, como tomada por um tom humorístico e triste que a afastava do perigo de viver. O conto finaliza com a protagonista indo dormir. "Antes de se deitar, como se apagasse uma vela, soprou a pequena flama do dia" (LISPECTOR, p. 41). Aqui, mais uma vez, a imagem da cegueira se insinua, através dos significantes "vela" e "flama", remetendo-nos ao encontro com o cego. Disso podemos fazer algumas observações. A primeira diz respeito ao lado sombra (recalque) para onde Ana retorna. O segundo, ao significante "cego" que a acompanha e a desnorteia. Segundo Freud (2010), a cegueira remete ao medo da castração, ao contato com o vazio que nos constitui. Ana, segundo a narradora, faz um gesto parecido com o de Édipo, ao apagar essa vela, soprando a pequena flama do dia. A Ana cabe esquecer, cometer uma cegueira simbólica para que esse vazio não mais se insinue, para que o recalcado não mais retorne e o inconsciente não se repita. Édipo cega-se a si mesmo, diante do horror do incesto. Segundo Freud (2010), esse ato é "apenas uma forma atenuada do castigo da castração, o único que lhe seria apropriado, conforme a lei de Talião" (FREUD, 2010, p. 346-7). Ambos cometem um ato voluntário, a fim de encobrir algo maior, traumático e amedrontador.

Se Ana prefere a cegueira noturna ao clarão do real, a protagonista de "A quinta história" faz algo parecido, mas de forma mais explícita e incisiva. O conto narra cinco histórias em torno de um mesmo tema: matar baratas, representando a insistência (na tentativa) da protagonista de expurgar algo que ameaça desestabilizar sua armadura subjetiva. A barata aí pode ser lida como o material estranho recalcado pelo ego e que, movido por uma compulsão, vem à tona durante a noite, momento em que as forças vigilantes desse mesmo ego são relaxadas no sono. De dia, diz-nos a voz que narra, "as baratas eram invisíveis e ninguém acreditaria no mal secreto que roía casa tão tranquila" (LISPECTOR, 1999a, p. 74). O material inconsciente e repelido fica à espreita de uma brecha para emergir com toda potência. É

${ }^{2} \mathrm{Em}$ A paixão segundo G.H, a narradora usa essa expressão (ostra) para se simbolizar o indizível, aquilo que aqui chamo de real, pensando no conceito lacaniano estruturante da subjetividade. Em Água viva a menção a essa ostra enquanto vida primária também aparece ao longo da narrativa. A ostra é o de dentro, o mais primitivo que contrasta com o de fora, o conhecido e resistente. 
na penúltima história que encontramos a narradora diante de uma certeza que a precipita a uma atitude definitiva. "Mas olho para os canos, por onde esta mesma noite renovar-se-á uma população lenta e viva em fila-indiana” (LISPECTOR, 1999a, p. 76). Portadora da certeza de que esse mal se repete e se renova a cada noite, resta-lhe, numa encruzilhada de sacrifício, escolher: "eu ou minha alma" (LISPECTOR, 1999a, p. 76). Como Ana, a mulher que tem "vida dupla de feiticeira" opta pelo eu, pela vida repetida no mesmo. "Escolhi. E hoje ostento secretamente no coração uma placa de virtude: 'Essa casa foi dedetizada"' (LISPECTOR, 1999a, p. 76, grifo meu). O mal secreto, por enquanto, foi repudiado por um ego controlador e retorna ao inconsciente. Assim como há uma quinta história que desdobra a história primeira, esse recalcado também retornará, insistindo em se representar na consciência, provocando estranhamento e gozo à narradora sádica. "Assim como as histórias retornam, ainda que aparentemente finalizadas, também as baratas voltam a escalar os canos do apartamento, como a virtualidade do mal que elas simbolizam" (ROSENBAUM, 2006, p. 138).

Em "A quinta história”, a decisão da narradora é pelo eu, instância que lhe assegura conforto psíquico e uma identidade estável. Dedetizada, a casa encontra-se protegida e segura, embora passível de ameaças futuras. Trata-se apenas de um paliativo contra uma força insistente que insiste em se representar. Algo foi apaziguado, mas a ameaça não perece.

Já no conto “A fuga”, a protagonista também escolhe recuar para o mundo estável da casa, mesmo sabendo que aí continuará a se afogar sem jamais "encontrar o fundo do mar com os pés". O conto é narrado em terceira pessoa e pode ser dividido em três momentos: o cotidiano alienante, a tentativa de fuga do mundo asfixiante da casa e, por fim, o retorno ao lar e a fuga desse universo sombrio pela fantasia. Essa seria a sequência cronológica, que não segue necessariamente a forma como os fatos são dispostos ao longo da narrativa. Esta, por sua vez, começa com a protagonista na rua, em meio a uma chuva, quase decidida a abandonar a vida de doze anos que levara com o marido e fugir num navio com o dinheiro que havia em casa. À medida que o texto vai progredindo, a personagem vai ganhando confiança na sua opção. Inicialmente, ela aparece imersa no medo e na dúvida, "porque ainda não resolvera o caminho a tomar". Teme que algo lhe devolva ao cotidiano e que a cena diária se recomponha e diz para si mesma, como se quisesse reforçar sua tênue decisão: "Você não voltará!". Ao mesmo tempo que tenta se assegurar de sua escolha, começa a reexperimentar a vida anterior que renascia nessas três horas de liberdade. E com ela, também nascia a certeza de que "as coisas ainda existem". Vivia, então, a alegria e o alívio misturado "a um pouco de medo e doze anos". Quando a chuva passa, como que batizada para uma 
nova possibilidade de existência, a protagonista, enfim, confirma sua escolha: "Não voltarei para casa. Ah, sim, isso é infinitamente consolador. Ele ficará surpreso? Sim, doze anos pesam como quilos de chumbo. Os dias se derretem, fundem-se e formam um só bloco, uma grande âncora” (LISPECTOR, 1979, p. 101). A partir daqui, entramos na segunda parte da narrativa, quando temos acesso ao momento em que a personagem decide fugir.

Como foi que aquilo aconteceu? A princípio apenas o mal-estar e o calor. Depois qualquer coisa dentro dela começou a crescer. De repente, em movimentos pesados, minuciosos, puxou a roupa do corpo, estraçalhou-a, rasgoua em longas tiras. $\mathrm{O}$ ar fechava-se em torno dela, apertava-a. Então um forte estrondo abalou a casa. Quase ao mesmo tempo, caíam grossos pingos d'água, mornos e espaçados. (LISPECTOR, 1979, p. 102)

Encontramos, nesse fragmento, a contenção de uma força que não suporta mais o peso dos dias e rebenta. A casa ruiu com um forte estrondo, ou seja, o eu aprisionado no cotidiano repressor ${ }^{3}$ não suporta mais segurar a vida que lhe exige. A forma como a personagem despe-se retrata essa urgência em se libertar dessas roupas que lhe amarram nos "doze anos que pesam como chumbo". Decidida, "juntou todo o dinheiro que havia em casa e foi embora" (LISPECTOR, 1979, p. 103). Neste momento, a narrativa retoma a vida da protagonista na rua, fazendo planos para o futuro. Os verbos agora não mais no passado, acompanham os devaneios da dona de casa:

\footnotetext{
Amanhecerá. Terá a manhã livre para comprar o necessário para a viagem, porque o navio parte às duas horas da tarde. $\mathrm{O}$ mar está quieto, quase sem ondas. O céu de um azul violento, gritante. $\mathrm{O}$ navio se afasta rapidamente... $\mathrm{E}$ em breve o silêncio. As águas cantam no casco, com suavidade, cadência.... Em torno, as gaivotas esvoaçam, brancas espumas fugidas do mar. Sim, tudo isso! (LISPECTOR, 1979, p. 103)
}

Como diz a voz que narra, "os desejos são fantasmas que se diluem mal se acende a lâmpada do bom senso" (LISPECTOR, 1979, p. 101). É apegada a esse fantasma que a protagonista devaneia um futuro em que possa experimentar a vida larga. A paisagem forjada pela fantasia recria uma atmosfera de paraíso: mar quieto, céu azul, silêncio, águas e gaivotas. Como num suspiro, logo em seguida, acendem-se as lâmpadas do bom senso. No plano formal, o texto é dividido por um espaçamento em branco como se uma linha abrupta cortasse o fio da fantasia e sobrepusesse ao princípio de prazer seu antagonista, o princípio de realidade. Da fantasia para a realidade: da viagem imaginária para a vida cotidiana. O que encontramos no parágrafo seguinte é uma cadência de oposições bem representadas pela adversativa "mas", que apresentam argumentos capazes de impossibilitar essa viagem

\footnotetext{
3 "Porque seu marido tinha uma propriedade singular: bastava sua presença para que os menores movimentos de seu pensamento ficassem tolhidos" (LISPECTOR, 1979, p. 101).
} 
desejada: "Mas ela não tem suficiente dinheiro para viajar. As passagens são tão caras" (LISPECTOR, 1979, p. 103). E prossegue elencando fatos para justificar uma possível vontade inconfessada de permanecer no mesmo, até que, negando essas desculpas, assume, de fato, o motivo verdadeiro:

\footnotetext{
Oh, tudo isso é mentira. Qual a verdade? Doze anos pesam como quilos de chumbo e os dias se fecham em torno do corpo da gente e apertam cada vez mais. Volto para casa. Não posso ter raiva de mim, porque estou cansada. E mesmo tudo está acontecendo, eu nada estou provocando. São doze anos. (LISPECTOR, 1979, p. 104)
}

Justifica-se a recomposição do cotidiano por conta dos hábitos que se enraízam e criam vida. Sem forças para reagir ao contrário, a protagonista atribui ao acaso essa decisão, fugindo de sua responsabilidade de escolher. Reitera sua opção, como se se justificasse, mais uma vez, por escolhê-la, atribuindo ao tempo a culpa por não poder romper a casca opressora dos dias. "São doze anos!" A partir daí, a narrativa passa a ser contada no presente, com verbos que criam o desfecho do dia com muita rapidez: "entra”, "diz”, “toma”, "veste”, "beija", "promete". O texto finaliza, de forma semelhante ao conto "Amor", com o casal indo dormir e a apagar a luz. "Pede ao marido que apague a luz. Ele beija-a no rosto e diz que o acorde às sete horas em ponto. Ela promete, ele torce o comutador" (LISPECTOR, 1979, p. 104). A protagonista nem tem coragem para realizar a ação, enclausurada num cansaço que tudo parece justificar. Ou estaria ela atribuindo - exclusivamente - ao marido a função de ocultar-lhe os dias, a responsabilidade de lhe abafar a vida?

Os três parágrafos finais, ainda que curtos, trazem a personagem novamente para o campo da fantasia, em que a realização do desejo é possível e a viagem, ainda que alucinada, acontece. Em contraste com a noite da personagem e a noite externa, "Dentre as árvores, sobe uma luz grande e pura”, como se anunciasse outra possibilidade para o sujeito acomodado em seus dias. Agora, dominada, mais uma vez, pelo desejo, a narrativa encena o movimento da fantasia a criar cenários interiores, a fazer viajar e experimentar mundos possíveis ao sujeito preso ao impossível: "Fica de olhos abertos durante algum tempo. Depois enxuga as lágrimas com o lençol, fecha os olhos e ajeita-se na cama. Sente o luar cobri-la vagarosamente" (LISPECTOR, 1979, p. 104). E, por fim, no último parágrafo: "Dentro do silêncio da noite, o navio se afasta cada vez mais" (LISPECTOR, 1979, p. 104).

Aqui podemos pensar esse navio que se afasta sob duas perspectivas: a do devaneio e a do princípio de realidade. Sob a primeira possibilidade, a personagem encontra saída para a frustração do desejo e viaja, criando um fantasma de viagem para se libertar da vida pesada que a condena nesse cotidiano infeliz. Nesse caso, viajar significa, através do devaneio, 
romper o cotidiano que a encrusta no peso dos dias. Já a segunda possibilidade remete ao princípio da realidade, cujos fatos acontecem sem as sombras do fantasma subjetivo. O sujeito toma consciência que perdeu a viagem e chora sua impossibilidade de se livrar dos braços dos doze anos pesados. O que vem à tona nesse jogo é a ideia de um sujeito em conflito, após ter repetido o prazer um dia abandonado em nome de uma vida estável. Subjacente a isso, digladiam-se Eros e Thânatos, cada qual tecendo fios diferentes. Um, de forma explícita, tenta recompor os laços, enredar a personagem em seu cotidiano, em sua família. Thânatos, por sua vez, de maneira silenciosa e sutil, empurra a protagonista para a viagem, para uma repetição compulsiva (penso aqui no tema da viagem bem representada pelo título "Fuga"), para a ruptura do laço, disforia do mesmo. Parece que, em todos os três contos aqui aludidos, a força de Eros se sobrepõe. Para tais personagens, mesmo que seja apertado o laço, é preferível a manutenção do mesmo à vivência da íntima desordem. A casa quase sempre é o reduto de Eros, recinto em que, às custas de sacrifício, o eu mantém-se em sua unidade e conservando a unidade maior: do lar, da família. A ordem e a integração são mantidas sob a pressão vigilante de um ego fraturado, apesar de resistente. Sob a suspeita da ameaça de uma força implosiva e caótica, a ordem, apesar de capenga, é assegurada a todo custo. A repetição aí se dá a favor da ordem e da manutenção do mesmo. Aqui, ela funciona como força inconsciente que nos impele a exercer os mesmos comportamentos, confirmando-nos em nossa identidade. Segundo Juan-David Nasio (2013), “[...] a repetição não tem uma finalidade exterior a si própria que ela busca alcançar. Essencialmente, ela é uma tendência irredutível que não tem outro fim a não ser permanecer sempre uma força que avança e nos arrasta para nos tornarmos mais nós mesmos" (p. 30). Nesse movimento, produzem-se três efeitos sobre o sujeito que vivencia tal experiência: preservação da sua unidade de indivíduo (autopreservação), desenvolvimento de suas potencialidades (desenvolvimento pessoal) e consolidação do sentimento de que ele é o mesmo ontem e hoje (consolidação da identidade). Diante desses efeitos benéficos da repetição, segundo Nasio, o sujeito consolida a sensação íntima de ser ele mesmo. "Numa palavra, Repito, logo sou" (NASIO, 2013, p. 30, grifo do autor).

O conto ainda, no que diz respeito ao tema da viagem e ao desejo de romper com o cotidiano, dialoga com o capítulo final de Perto do coraşão selvagem. "O navio flutuava levemente sobre o mar como sobre mansas mãos abertas. Inclinou-se sobre a murada do convés e sentiu a ternura subindo vagarosamente, envolvendo-a na tristeza” (LISPECTOR, 1998, p. 196-7). Diferente da figura central de "A fuga", Joana empreende sua travessia em busca do objeto desejado, embora nunca o atinja em sua totalidade (SILVA, 2018). Rompe com tudo que a aprisiona, certa de que "de qualquer luta ou descanso me levantarei forte e bela como um 
cavalo novo" (LISPECTOR, 1998, p. 202). Joana começa a travessia, inicia o périplo que será completado por G.H, que vislumbra a coisa na própria coisa. [...] "Muitos foram os que abandonaram tudo o que tinham, e foram em busca da fome maior" (LISPECTOR, 1968, p. 183).

\section{O destino maior}

GH, diferente dessas personagens dos contos supracitados, não resiste aos apelos de uma pulsão de desordem e, numa viagem afirmativa, entrega-se à desagregação de si, faz a sua via crucis e consuma sua própria tragédia. Eis como ela mesma narra esse chamado interior:

Mas por que exatamente em mim fora repentinamente se refazer o primeiro silêncio? Como se uma mulher tranquila tivesse simplesmente sido chamada e tranquilamente largasse o bordado na cadeira, se erguesse, e sem uma palavra - abandonando sua vida, renegando bordado, amor e alma já feita - sem uma palavra essa mulher se pusesse calmamente de quatro, começasse a engatinhar e a se arrastar com olhos brilhantes e tranquilos: é que a vida anterior reclamara e ela fora. (LISPECTOR, 1968, p. 82)

O trecho, ainda que sutilmente, faz alusão ao texto bíblico, quando traz à baila a ideia do chamado, remetendo-nos de imediato ao convite/apelo realizado por Deus aos patriarcas e aos profetas. A alusão paródica é feita ainda aos textos da própria autora, quando traz à tona a figura da mulher enredada em seu cotidiano que, ouvindo essa voz que clama no deserto interior, é capaz de largar tudo e ir. Aqui lembramos, mais uma vez, de Ana e da heroína de "A fuga", presas nesse bordado inacabado qual Penélope à espera de um dia tranquilo. Como esta, aquelas asseguram a vida no tecer os dias, mergulhadas em seus afazeres cotidianos. Sua alma já feita, para continuar estável, precisa desse bordar constante. Por isso, elas se apegam e se agarram a essa tábua de salvação, protegendo a vida da desagregação, da ameaça contínua que advém de dentro delas mesmas. A atitude de $\mathrm{GH}$, do contrário, remete a uma ruptura dessa alma formada. Ela faz o percurso semelhante ao dos profetas (acolhem a ordem de Deus/pulsão), numa atitude de criança, desconstruindo a ideia de uma identidade plena. Como criança, aceita o jogo do devir. A criança, segundo o Nietzsche de Assim falou Zaratustra (2008), é "a inocência, [...] e esquecimento, um novo começo, um jogo, uma roda que gira por si mesma, um movimento inicial, um sagrado dizer 'sim" (NIETZSCHE, 2008, p. 53). É, portanto, com a coragem dessa criança que G.H. realiza a transmutação de si, permitindo que se quebrem os invólucros de uma identidade cristalizada, caminhando em direção ao inumano. 
É por essa busca do não eu, o retorno a um mundo sem forma e sem fundo, que a narradora de A paixão envereda. Entretanto, largar tudo e partir num caminho ao revés não é trabalho simples para quem viveu confortavelmente num eu estabilizado. O caminho é, como a paixão de Cristo, permeado por incertezas, solidão, angústia e muito sofrimento. Despir-se de uma alma já formada é para os fortes e obstinados, para os que compreendem a vida como potência, força a ser experimentada em todas as circunstâncias. Repetir-se, nesse gesto afirmativo é, para a protagonista, viver no limiar do gozo, em que se entrelaçam vida e morte, prazer e sofrimento, angústia e vazio, sadismo e masoquismo. Abeirar-se da trilha de volta requer assumir sua própria morte, deixar-se banhar na crueldade de uma pulsão que não encontra satisfação senão na própria atividade insistente e reiterada, fazendo do sujeito um joguete inocente, passivo e feliz.

Antes de enveredar pela porta estreita da barata, retornando do mundo já formado para o caos da vida ainda em sua potência, a protagonista, como aquelas do conto, tinha uma vida equilibrada que lhe possibilitava conforto e segurança dentro de sua crisálida subjetiva. [...] "numa pessoa organizada eu me encarnava, e nem mesmo sentia o grande esforço de construção que era viver. A ideia que eu fazia de pessoa vinha de minha terceira perna, daquela que me plantava no chão" (LISPECTOR, 1968, p. 08-9). Cristalizada nessa forma organizada, fruía dos dias sem muito esforço e se reconhecia naquilo que os outros confirmavam como sendo sua identidade: "Naquela manhã, antes de entrar no quarto, o que eu era? Era o que os outros sempre me haviam visto ser, e assim eu me conhecia" (LISPECTOR, 1968 , p. 24). Entretanto, toda essa armadura construída em torno de uma felicidade apaziguada será demolida a partir do momento em que G.H. adentra no quarto da empregada, movida por um desejo de ordem. O que ocorrerá, a partir daí, é o seu avesso, a instalação de uma desordem transformadora perante um vazio que se insinua e se revela com a potência de uma falta, como numa antecâmara da morte. "Da porta eu via agora um quarto que tinha uma ordem calma e vazia” (LISPECTOR, 1968, p. 42). Dentro do quarto de G.H., só havia a nudez. A cama, sem lençol, expunha o colchão de pano empoeirado, cheio de manchas antigas e pálidas. O pano, por sua vez, estava furado, deixando à luz um vazio inevitável. Nem mesmo as três malas velhas eram capazes de alterar "o vazio do quarto”. O guardaroupa, estreito, “abria-se em gretas e farpas". Portanto, encontra-se a protagonista num espaço que, embora ocupado materialmente, sedu-la por lhe revelar o contrário.

Para colmatar esse vazio, G.H. decide arrastar tudo para o corredor e jogar no quarto baldes de água a fim de enlamear a poeira e fazer surgir a umidade, movida por um desejo até então desconhecido de "matar alguma coisa". Além disso, cobriria o colchão de palha 
com um lençol leve, rasparia da parede a secura do carvão, apagando a palma exposta das mãos, do homem, destruindo a cabeça pequena demais para o corpo daquela mulherona nua. Por fim, "Como se já estivesse vendo a fotografia do quarto depois que fosse transformado em meu e em mim, suspirei de alívio” (LISPECTOR,1968, p.50).

Fascinada por essa trama de vazios, a protagonista vê-se jogada numa trilha sem escapatória cujo imperativo maior implica retornar. Como que sorvida por essa pulsão de abismo, ela, como cego, vai em direção ao não-ser. Para tanto, precisa passar pela "porta estreita", o caminho doloroso da barata, com quem estabelece uma relação objetal. Isso se dá num processo de reencontro com o objeto perdido que se faz agalma no semblante do inseto, remetendo a personagem a esse lugar de falta. Adentrar por essa porta ornamentada da barata significa ir em direção a uma outra coisa que se mostra num vislumbre repentino e desaparece da mesma forma, deixando apenas as marcas no corpo de quem contemplou. Lacan, no Seminário 8 (A transferência), trabalha o termo agalma (tesouro, enfeite) como algo que está no interior e que se trata sempre de uma outra coisa. Esse objeto nos apaixona ou seduz porque contém, escondido em si, o objeto do desejo, o agalma. Trata-se sempre de um objeto parcial. "É esta alguma coisa que é visada pelo desejo como tal, que acentua um objeto entre todos, por não ter comparação com os outros. É a essa acentuação do objeto que responde a introdução, em análise, da função do objeto parcial” (LACAN, 1992, p.149).

A barata torna-se para G.H esse objeto precioso que contém algo maior, portadora de um tesouro escondido. Depois G.H. depara-se com a ilusão: [...] "rastejei até as portas se abrirem para mim, as portas do tesouro que eu procurava: e olha o que era o tesouro!" (LISPECTOR, 1968, p. 163). Essa relação objetal passa por algumas etapas, oscilando entre aproximação e afastamentos, atração e repulsa, para culminar na devoração da coisa.

Obstinada em sua hybris, como a maioria dos personagens claricianos, G.H. não se contenta apenas com o que vê. Quer mais, pois "ter experimentado já era o começo de um inferno de querer, querer, querer... A minha vontade de querer era mais forte do que a minha vontade de salvação?” (LISPECTOR, 1968, p. 87). A resposta para esta auto-indagação é positiva, se pensarmos a salvação como retorno ao comodismo do eu e adequação a uma forma. Do contrário, num gesto afirmativo, ela continua a abrir as portas vazias que se lhe apresentavam, totalmente dominada por sua paixão: "Eu já estava vendendo a minha alma humana, porque ver já começara a me consumir em prazer, eu vendia o meu futuro, eu vendia a minha salvação, eu vos vendia” (LISPECTOR, 1968, p. 91). Como Joana, G.H. também estabelece um pacto fáustico com as forças desagregadoras em troca da vida em sua potencialidade primária. Essa barganha, como todo pacto, requer um sacrifício, o mesmo feito pela 
narradora de "A quinta história". Só que aqui a escolha é diferente: a opção é pela alma, janela sempre aberta a uma satisfação sempre adiada e recomeçada. Abrir a porta e atravessar o limiar da sua própria morte é ato de coragem, gesto afirmativo de quem aceita a vida em suas contradições, de quem parte da afirmação da morte, arqui-inventa a si mesma ao invés de aceitar um modelo pré-estabelecido. G.H. sabe lidar com o conflito que é a escolha de cada situação, sem atribuir tal decisão nem a Deus (ou consolos metafísicos) nem à moral estabelecida. Compreende que, independentemente de sua história, existe um instante supremo e, nesse momento, é seu gesto que determina. A protagonista, portanto, apesar da dor, tem a capacidade de ler a si mesma, rever-se e construir-se nessa travessia contínua. Nessa ação, o sujeito experimenta a vida não mais como estaticidade, mas pura tensão, embate contínuo entre forças que ora agregam, ora desagregam: [...] terei que correr o sagrado risco do acaso. E substituirei o destino pela probabilidade" (LISPECTOR, 1968, p. 10). A coragem afirmativa de G.H. não significa que o sujeito enfrenta seu fatum corajosamente, alijando definitivamente todo sofrimento. Pelo contrário, o percurso é todo atravessado por medo, aceitação, recuos e indecisão. Mas, malgrado tudo isso, prevalece a vontade de se perder:

Vida e morte foram minhas, e eu fui monstruosa. Minha coragem foi a de um sonâmbulo que simplesmente vai. Durante as horas de perdição tive a coragem de não compor nem organizar. E sobretudo a de não prever. Até então eu não tivera a coragem de me deixar guiar pelo que não conheço e em direção ao que não conheço: minhas previsões condicionavam de antemão o que eu veria. (LISPECTOR, 1968, p. 14)

Esse caminho às cegas implica pôr-se à beira do nada e correr os riscos de não mais reencontrar-se ao tocar as bordas do ilimitado, do sem sentido. Restam-lhe as mãos vazias e o sentimento de que a vida é esse desencontro que, por sua vez, precisa ser sempre recomeçado. [...] "Não esquecer que o erro muitas vezes se havia tornado o meu caminho. [...] Meu erro, no entanto, devia ser o caminho de uma verdade: pois só quando erro é que saio do que conheço e do que entendo" (LISPECTOR, 1968, p. 131). G.H. põe-se diante da vida de forma sisifiana, nesse abrir permanente das portas sem fundo, entradas labirínticas que nos remetem a outros portais. Joana relança-se na viagem. G.H, por sua vez, está sempre a abrir as portas vazias; a personagem de Água viva, por sua vez, a relançar a flecha da escrita, errando sempre o alvo. Assim são feitas as heroínas claricianas, sujeitos para quem o mundo é o lugar do embate, do recomeço permanente. "Não há um ato em que eu não me lance todo. $\mathbf{E}$ a grandiosidade da vida é lançar-se - lançar-se até mesmo na morte" (LISPECTOR, 1999c, p. 157, grifo meu). 
Imersa totalmente no seio da indiferença e banhada na terrível alegria indiferente, eis que G.H. é tomada pela tentação de comer. Abocanhar essa coisa viva que se insinua para além da barata aparece para a personagem como possibilidade de preencher um vazio vislumbrado no quarto, no esboço rabiscado na parede, no interior de si mesma.

A tentação é comer direto na fonte. A tentação é comer direto na lei. E o castigo
é não querer mais parar de comer, e comer-se a si próprio que sou matéria igual-
mente comível. Eu procurava a danação como uma alegria. Eu procurava o mais
orgíaco de mim mesma. Eu nunca mais repousaria: eu havia roubado o cavalo de
caçada de um rei da alegria. Eu era agora pior do que eu mesma! (LISPECTOR,
1968, p. 153-4)

Ao ingerir a matéria da barata, G.H. depara-se com o real e percebe que há um furo no Simbólico, toma consciência de que existe um vazio na própria estrutura simbólica. Diante desse choque que reverbera no corpo da voz que narra, a protagonista é tomada pela experiência do trauma. Pelo gesto devorador, G.H. tenta cobrir um hiato que lhe veio à tona ao adentrar no quarto vazio da empregada. Entretanto, o conteúdo da hóstia primitiva insiste em permanecer em seu lugar, como resto não simbolizável, como algo insosso, ao que não tem qualidade nem sentido, permanecendo como vazio que sempre foi. G.H. entende que, ao ingerir o material primário da barata, continuava querendo novamente o acréscimo. " $\mathrm{E}$ isso era aterrador, eu sempre tive medo de ser fulminada pela realização, eu sempre havia pensado que a realização é um final - e não contara com a necessidade sempre nascente" (LISPECTOR, 1968, p. 208). G.H., portanto, depara-se novamente com a fome, com a carência, seu destino maior, porque, enquanto ser de desejo e de linguagem, "somos garantidos por uma necessidade que se renovará continuamente".

Por fim G.H. completa sua despersonalização, esse caminho inverso em direção àquilo que a constitui. Trata-se da destituição do individual inútil, "a perda de tudo o que se possa perder e, ainda assim, ser”. Excluir todas as suas características, a maior exteriorização a que se chega. Através desse ato, ela se aproxima "daquilo de que se vive - e por não ter nome só a mudez pronuncia". Aproxima-se do indizível, do real, do inexpressivo, do impalpável. G.H. perfura a máscara humana e descobre que dentro no fundo de si mesma nada há, senão o vazio informe do neutro noturno, o profundo abismo do inexpressivo. Nesta fulguração ofuscante, em que ver é ver abismos, ela aprende que o homem não tem dentro, que deus não tem dentro. Dentro do humano há o inumano. Se não se tem nada dentro, nada há para exprimir. A única linguagem própria do inumano é o inexpressivo (SOUZA, 1997).

Diante do real, restam a mudez e a obstinação em representá-lo por meio do simbólico. "A realidade, antes de minha linguagem, existe como um pensamento que não se pensa". Apesar disso, o sujeito resiste a esse silêncio primordial e cava a todo custo um sentido no 
seio desse vazio. "A linguagem é o meu esforço humano. Por destino tenho que ir buscar e por destino volto com as mãos vazias. Mas volto com o indizível" (LISPECTOR, 1968, p. 212). Por meio da repetição na linguagem, no simbólico, o real aparece, mostra-se, escondese e se evola novamente para seu lugar de silêncio.

Este mesmo salto afirmativo fora dado por Joana e pela narradora de Agua viva. Neste livro, a autora evidencia o gesto repetido no ato do fazer poético e faz da repetição condição mesma dessa escrita nômade. Repetir é procurar, no seio da linguagem, um sentido que se mostra escorregadio, sempre outro. Metáfora da literatura, este empilhamento das palavras já ditas, este texto é o lugar onde a repetição se faz continuamente, resultado da tensão entre o achar e o perder, jogo de máscaras entre fazer e desfazer-se. Aí a voz que narra mergulha na palavra e faz uma aventura fascinante e desesperada por existir. Nessa agonia ritmada pela alegria e pela dor, a protagonista-narradora, assume também o risco da metamorfose, faz um mergulho nas zonas abissais para experimentar a vida em sua força titânica e, por fim, assume os riscos dessa vida lacerada que se lhe mostra. "Eu amo a minha cruz, a que dolorosamente carrego. É o mínimo que posso fazer de minha vida: aceitar comiseravelmente o sacrifício da noite" (LISPECTOR, 1973, p. 46). Encontram-se, aí, reverberações do amor fati nietzschiano, amor ao destino, à vida como ela é, ainda que esta venha imbuída em sofrimentos. $\mathrm{O}$ amor fati, ao invés de desviar o olhar diante dos sofrimentos, é o assentimento, o dizer sim para com a realidade. Não uma resignação em face da fatalidade inelutável, mas, do contrário, a aceitação alegre, e mesmo o fato de sentir a necessidade como uma forma de beleza.

Em Perto do coração selvagem, Joana também faz opção pela vida larga, pela vertente dionisíaca da existência. Segundo Ronaldes de Melo e Souza (1997), a narrativa de Clarice Lispector representa o drama da conversão da ordem apolínea do dia na paixão dionisíaca da noite. "No ritmo de transe do apolíneo diurno para o dionisíaco noturno, os possíveis narrativos são negados e renegados" (SOUZA, 1997, p. 123). Essa "poética dionisíaca" iniciase quando Joana empreende essa trajetória, mergulhando no universo sombrio e tenebroso da pulsão dionisíaca. Isso se processa em forma de dramas cuja culminância se dá com a "Viagem" (título do capítulo final do romance), travessia da ordem solar para a paixão dionisíaca. Esse rito de passagem culmina, segundo Souza, no monólogo interior, traduzindo a liberação do fluxo do devir, mediante o transe da forma estática da vida na mobilidade da vida em si mesma. Tomada pela potência afirmativa de um desejo que se lança continuamente no campo do Outro, a heroína vê-se diante da vida em seu ciclo ininterrupto. Como um herói do absurdo, aceita-a, toma para si o sentido de sua existência e mantém-se na rota do devir. Percebe que há uma tensão inconclusa, que existe a impossibilidade de um fechamento, 
pois nada está apto a satisfazer sua fome e é aí que residem seu gozo e o seu querer-mais, porquanto a aproximação do fim pode igualmente converter-se num novo começo e numa nova direção, lá onde o coração selvagem mostra-se e se fecha em sua inacessibilidade.

\section{Considerações finais}

Busquei, neste texto, evidenciar como as escolhas subjetivas na obra de Clarice Lispector são feitas, tomando como opções as vertentes dionisíacas e apolínea da existência. $\mathrm{Na}$ perspectiva nietzscheana, o apolíneo caracteriza-se como uma das duas pulsões da natureza e é pensado como fonte das artes plásticas, artes da visão, da pintura. Diz respeito às belas aparências, à luminosidade, ao equilíbrio, ao princípio da individuação, da imagem idealizada, purgada das imperfeições da realidade. Já o dionisíaco, por sua vez, caracteriza-se pela oposição à ordem apolínea, pela embriaguez sexual e orgiástica, pela ruptura das fronteiras, notadamente a ruptura da individuação, a abolição da personalidade. Esse princípio exprime uma certa compreensão do devir, pensado como potência irresistível de metamorfose. Tratase de um misto de horror e êxtase devido à perda da humanidade do indivíduo e sua reconciliação simultânea com a totalidade.

Nos contos aqui analisados, constatamos o predomínio da vertente apolínea, quando as personagens, mesmo experimentando um desejo de desordem, recolhem-se em seus mundos e optam pelo equilíbrio, pela falsa harmonia. Nessas escolhas, a casa funciona como recinto do apaziguamento, instrumento para reatar o laço e prender um nó que, apesar de incomodar essas mulheres, evitam a desagregação subjetiva, impedindo-as de fazer a experiência maior.

Diferentemente dessas personagens que retornam ao equilíbrio doméstico, G.H. faz um caminho mais arriscado, deixando-se perder na comunhão sacrílega com a barata. Consequentemente, ela faz o caminho da dissolução de si, num gesto de coragem e heroísmo. G.H., portanto, faz a opção pela vida larga, banhando-se na pulsão dionisíaca. Nesse gesto, afirma a vida, aceitando-a em suas contradições e - sobretudo - em sua tragicidade. Nessa mesma categoria, estão outras duas personagens clariceanas: Joana e a narradora de Água viva, sujeitos que se dilaceram nas suas escolhas por aceitarem o caminho mais difícil.

Eu ou minha alma? É nessa encruzilhada hamletiana que as personagens de Clarice Lispector se encontram. A decisão sobre qual polo seguir é, como vimos, sempre a do sacrifício. As que escolhem o eu, mantêm-se no equilíbrio de uma identidade organizada, conservam uma subjetividade apaziguada. Entretanto, vivem enredada em seus lares, num conformismo que as aprisionam e sufocam-na. Do outro lado, as que escolhem a alma enveredam 
pelo caminho da dor, da dissolução subjetiva e da desordem. Vivem a laceração dionisíaca, experimentam a vida em sua tragicidade e deparam com o absurdo de existir.

Esse último parece ser o caminho escolhido por Clarice em sua ficção, quando a autora denuncia a existência inautêntica e a vida conformada na mesmidade de Eros e representa personagens que se aventuram no caminho mais largo, movidas por uma potência que as leve a experimentar outras possibilidades, outras formas de ser. A escolha pela alma nunca é sem dor, nunca é apaziguada. Essa opção é a opção pelo desejo, pelo devir, pela pulsão de morte, signos do movimento, do caminho, da viagem, da travessia, da incompletude, da repetição e, portanto, do recomeço.

\title{
ME OR MY SOUL: \\ SUBJECTIVE CHOICES IN THE FICTIONAL UNIVERSE OF CLARICE LISPECTOR
}

\begin{abstract}
I highlight the theme of subjective choices in the work of Clarice Lispector, to demonstrate how some of her characters make these options effective from two poles: on the one hand, the preference for the Apollonian face of existence; on the other, the election of the Dionysian strand, culminating in the affirmative gesture. To this end, I choose as a corpus the tales Love, from Family ties, The Fifth Story, from The Foreign Legion, The Escape, from Beauty and the Beast and the novel The Passion according to G.H. As a theoretical support, I use Psychoanalysis and Nietzschean philosophy. This is a work of a bibliographic nature based on the methodology of comparative literature.
\end{abstract}

KEYWORDS: Subjective choices; Apollonian and Dionysian strands; Affirmative gesture; Clarice Lispector.

\section{REFERÊNCIAS}

ABBAGNANO, Nicola. Dicionário de filosofia. 5. ed. São Paulo: Martins Fontes, 2007.

FREUD, Sigmund. O inquietante. In: __. História de uma neurose infantil: ("O homem dos lobos"), Além do princípio do prazer e Outros textos (1917-1920). Trad. e notas Paulo César de Souza. São Paulo: Companhia das Letras, 2010.

Kierkegaard, Soren. O conceito de Angústia. Lisboa: Hemus editora, 1968

LACAN, Jacques. O seminário, Livro 8: A transferência. Rio de Janeiro: Zahar, 1992.

LISPECTOR, Clarice. A legião estrangeira. Rio de Janeiro: Rocco, 1999a. - A descoberta do mundo: crônicas. Rio de Janeiro: Rocco, 1999b. . Um sopro de vida: pulsações. Rio de Janeiro: Rocco, 1999c.

. Perto do coração selvagem. Rio de Janeiro: Rocco, 1998.

- A bela e a fera. 2. ed. Rio de Janeiro: Nova Fronteira, 1979.

- Laços de família. 29. ed. Rio de Janeiro: Francisco Alves, 1997.

- A paixão segundo G.H. 2. ed. Rio de Janeiro: Sabiá, 1964.

. Água viva: ficção. 2. ed. Rio de Janeiro: Artenova, 1973. 
NASIO, Juan-David. Por que repetimos os mesmos erros. Tradução de André Telles. Rio de Janeiro: Zahar, 2013.

NIETZSCHE, Friedrich. Assim falou Zaratustra. Tradução de Mário da Silva. 17. ed. Rio de Janeiro: Civilização Brasileira, 2008.

ROSENBAUM, Yudith. Metamorfoses do mal: uma leitura de Clarice Lispector. São Paulo: Editora da Universidade de São Paulo: Fapesp, 2006. (Estudos de Cultura; 17).

SILVA, Gilson Antunes da. Desejo e solidão: uma leitura do romance de Clarice Lispector. Curitiba: Appris, 2018.

O cenário da dispersão passional: matizes do infantil em Clarice Lispector. Revista Inventário, 9 ed. 2011. Disponível em < http://www.inventario.ufba.br/09.htm>. Acesso em 14 de maio de 2015.

Cantilenas afirmativas: a poética da repetição de Clarice Lispector. 2015, 257f.Tese (Doutorado em Literatura e Cultura) - Instituto de Letras - Programa de Pós-Graduação em Literatura e Cultura, Universidade Federal da Bahia, Salvador, 2015.

SOUZA, Ronaldes de Melo e. A poética dionisíaca de Clarice Lispector. Revista Tempo Brasileiro, Rio de Janeiro, n.130/131, p.123-43, 1997.

Recebido em: 28/09/2020.

Aprovado em: 03/11/2020. 